Ende specialijck beloven ende sweeren wij bij dezen, dat wij noijt trachten zullen, ymant van het Mahumetis gevoelen afteleijden, maar zullen die vande gantsche cust van Hitoe ende wie elders meer van dat gevoelen zijn, van ons daarin ongemolesteert werden gelaten. .

Zoo zullen wij oock niet gecloogen, eenige jonge lieden van het Moors gevoelen, zonder speciael consent van haare ouders ende vrunden, met eenige Christen dochters trouwen ende midsclien, gelijck als dat dan volgen moet, Christen werden, maar nemen wij aen ende beloven, d'ouders ofte momboirs ${ }^{1}$ ) van zoodanige onmondige kinderen daar van te laten weten ende indien zij daerinne niet willen consenteren, dezelve weder datelijck tot hen te stieren. Soo waerlijck moet ons Godt almachtich helpen.

Aldus gepasseert ende beswooren in het Casteel Victoria in Amboina dezen seven-en-twintichsten April $\mathrm{A}^{\circ}$ 1651. ${ }^{2}$ )

\title{
CXCVIII. AMBON.
}

5 Mei 1651. ${ }^{3}$ )

„Volgens d'expresse ordre van haare $\mathrm{Ed}^{\mathrm{n}}$ in Batavia” heeft De Vlamingh den 5 Mei 1651 ,,aen alle vreemclelingen bij publicque edicte gepreadverteert, van naar dezen noijt weder hier inde landen te verschijnen" (Onuitgegeven „Verbael” van De Vlamingh, waaruit ik onderstaand stuk overneem).

Placcaet noopende de vaert der vreemdelingen naar Amboina.

Arnold de Vlamingh van Oudtshoorn, Ordinaris Raadt van India, out gouverneur ende directeur dezer provintie Amboina, midsgaders admirael encle superintendent, als oock expresse commissaris der emportante gouvernementen Molucos, Amboina ende Banda, van wegen d'Hoo: Mogende Fleeren Staten Generaal, Zijn Hooch ${ }^{t}$ Willem Frederick, bij der gratie Godes prince van Orangien, grave van Nassouw et ${ }^{\mathrm{rn}}$, onder 't beleijt vanden $\mathrm{Ed}^{\mathrm{n}} \mathrm{H}^{\mathrm{r}}$ Carel Reniersz, gouverneur generaal over gants Nederlands Indien, allen den geenen

1) Mombers : voogden.

2) Valentijn, t.a.p., heeft hier nog (bldz. 173) de onderteekeningen.

3) Uit Oiẹrgekonen bricven en papicren 000, 1652, III, fol. 245, v. 
die dezen zullen zien ofte hooren lezen, saluyt; (loet te weten: alzoo wij geduerendt ons gouvernement in deze landen van tydt tot tijdt hebben aengemerckt, hoe dezelve zeer lichtelijck met factien, invasien, vele onrusten ende bijzonderlijcke contraminatien tegen de solemnele contracten tusschen de Comp" encle alle haare goede onderdanen als bondtgenoten aengegaen, bij continuatie vande jaarlijckse aencomende als retournerende vreemdelingen uijt verscheyde gewesten ende landen herwaerts aen hunnen particulieren handel met rijs ende verscheijde minudentien ${ }^{1}$ ) eenlijck voor comptanten (edoch slechts soo veel ons maar openbaar can werden) te trockeren ende negotieren, zyn verschijn[en]de(?), gestadichlyck zouden connen werden gehouden in een onseeckeren stant, waardoor onze voorschreven inlanderen, alschoonse hun tot d'effective ware daet noijt mochten comen te verloopen, niet alleen geduerichlyck met aenvechttingen ende innerlijcken strijt, gehelijck met 's menschen ongematichde begeerlijckheijt accorderende, tot alzulck een ongeoorloft ende averechts gewin aengedreven ende bestreden, maar oock bij dadelijcke transgressien der meergeschreven zoo heijlich geswoorne contracten, door 't veralieneren van een eenige self d'allerminste quantiteijt harer nagelvruchten, of wat daar slechts eenigen reuck of smaack van is behoudende, in overgroot peryckel, zoo wij zulcks mochten gewaar worden, van niet enckelyck al geheel hun landt, sant ende alles wat ter werelt bezitten, maar oock als meyneedige met de hoochste infamie hun lyf ende bloet souden comen rechtveerdichlijcken te verbeuren. Zoo ist, dat wij, willende onze welgemelde goede ende lieve onderdanen zoo wei van zoodanigen effectieven capitalen misdaet als selfs oock van 't perijckel van t'eeniger tydt door de hooge aanbiedingen, bekoorlyckheden, als looze traductien van voornoemde vremde onchristen negotianten, daar toe te vervallen, tharen segoure gerustheijt bevryden, ende oock alzoo d'E: Compagnie in hare gerechtige possessie dezer trafficque naar onzen plicht soo veel doenlijck asseureren ende buijten alle nadencken confirmeren, hebben met voorgehouden communicatie ende approbatie van onze Ed ${ }^{e}$ Hoochgeduchte $\mathrm{H}^{\text {ren }}$ gebieders, den $\mathrm{Ed}^{\mathrm{en}} \mathrm{H}^{\mathrm{r}}$ Gouverneur Generaal ende Ed'. Heeren Raden van India in Bat $^{a}$ uijt krachte van haare daertoe gegeven specialen last, expresselijck verboden ende g'interdiceert, zoo wij expres verbieden ende interdiceren bij dezen, alle onchristen uijtheemse volckeren ofte vreemdelingen, van wat staat ofte conditie die zoude mogen wezen,

1) Minudencia (Port), kleinigheid (Spaansch: menudencia). 
oijt ten eeuwigen dage, alie pretexten, hoeze oock zouden mogen genaemt zijn, uijtgeslooten, in deze landen van Ámboina, zoo wel die onder de souveraniteijt vande $\mathrm{E}$ : Compagnie als onder den Ternataensen Coningh ende bij solemneel verdrach ende verbondt onder meergeschreven E. Compagnie zijn sorterende, met hunne 't zij joncken, chiampans, prauwen ofte eeniger hande vaertuijgh, 't zij met ofte zonder ladinge ofte negotie, naar de publicatie dezes meer te verschijnen, op poene van vaertuijch ende alle goederen voor d'E: Compagnie te zullen werden verbeurt, encle daarenboven alle de menschen voor al haar leven inde keten gekloncken ende geduerich in slavernije gehouden te werden, want wij zulcks tot de bloeijende rust ende vreede dezer landen ende welstandt van d'E: Compagnie alzoo bevinden te behooren.

Amboina dezen $5^{\wedge n}$ Maij $A^{\circ}$ 1651. Was geteeckent Arnold de Vlamingh van Oudtshoorn.

\section{BASRA.}

\section{Mei-17 Angustus 1651. ${ }^{1}$ )}

„De eerste reis der Nederlanders door de Perzische golf” vond plaats in 1645 onder leiding van Cornelis Cornelisz. Roobacker (A. Hotz in het Tijdschrift van het Koninklijk Nederlandsch Aardrijkskundig Genootschap, 2e serie, XXIV, 1907, bldz. 289 v.v.). Moeilijkheden met Perzië (Hotz, t.a.p., bldz. 296, v.v.; Corp. Dipl., I, bldz. 370, 490, v.) leidden de O. I. C. tot het aanknoopen van betrekkingen met Basra $\left(30^{\circ} 30^{\prime}\right.$ N. B., $47^{\circ} 40^{\prime}$ O. L.), gelegen by den Sjatt-el-Arab.

Volgens Boudaens „relaes” (zie beneden) was Basra toen een „reedelycke groote ende (op die landtswijzen) wel betimmerde stadt". Ook de Engelschen dreven daarop van Surat uit een voordeeligen handel en hebben daar ,een eygen woningh". Vroeger had de stad gestaan "onder het ver gebiedende Ottmanse huys", maar zij werd nu ,door Haasen ${ }^{2}$ ) bassia met absolute ende conincklycke macht gegouverneert" en wel ,; door erfenisse van zijn vader ende grootvader". „Echter gebruycken noch den schijn gelijck dependent van den grooten Turck, op wiens naam de tollen noch gevordert werden, doch geniet in 't minste daer niet van, als alleenelijck jaerlijcks, gelijck tot een erkentenisse, weynich schenckagie. (Vgl. hierbij Hotz, t.a.p., bldz. 394, v.; R. Hartmann in Enzyklopaedic des Islam, I (Leiden, Leipzig, 1913, S. 701). Deze stad werd beschouwd als zeer goed

1) Uit het Contractboek. In Oiergekonlen brieven en papicren 000, 1652, komt mede een afschrift voor, dat sommige onduidelykheden in onderstaanden tekst . verduidelijkt.

2) Hoesain pasja. 